\title{
PRI Financing: 1998-1999 Trends and Statistics
}

\author{
by Loren Renz, Vice President for Research
}

\section{Overview of PRI Activity for All Foundations}

In 1998, the nation's nearly 47,000 active private and community foundations made charitable distributions totaling nearly $\$ 22$ billion. Grants of $\$ 19.5$ billion accounted for the vast share of these distributions. Nonetheless, for some foundations, grantmaking was not their only charitable activity. Among the alternatives to grantmaking, foundations reported $\$ 203.4$ million in charitable loans and other program-related investments (PRIs). ${ }^{1}$ These asset-based funds provided lowor no-interest loans to organizations, capitalized community loan funds and venture capital funds, or were invested in charitable use property.

In 1999 , over 50,000 active foundations paid $\$ 23.3$ billion in grants, an increase of almost 20 percent over the prior year. During the same period, foundations reported a 31 percent increase in new program-related investments, from $\$ 203.4$ million to $\$ 266.5$ million. ${ }^{2}$ The 1999 increase came on the heels of exceptionally strong growth in PRIs between 1997 and 1998. Since 1997, annual PRI distributions have climbed by more than four-fifths. ${ }^{3}$ The rapid rise in PRI financing was closely tied to the stock market boom of the late 1990s, which greatly increased the value of foundations' endowments. During periods of rapid asset growth, foundations are more likely to leverage a portion of their assets in the form of charitable loans and investments. The growth in PRI financing may also reflect the long-term impact of funder education efforts sponsored in the early and mid-1990s by two foundations that pioneered the use of PRIs - the Ford Foundation (NY) and the John D. and Catherine T. MacArthur Foundation (IL).

Although the level of PRI financing soared in the late 1990s, the number of active PRI funders has remained fairly steady. The new PRI Directory includes descriptions of 192 PRI providers, up only slightly from the number identified in the Center's first

1. See Lawrence, S. et al., Foundation Yearbook : Facts and Figures on Private and Community Foundations, New York: Foundation Center, 2000.

2. Total 1999 PRI amount for all foundations is based on data compiled for the PRI Directory, 2001. Figures reflect distributions paid in circa 1999 and therefore included in foundations' qualifying distributions.

3. See Renz, L. et al., Foundation Giving: Yearbook of Facts and Figures on Private, Corporate and Community Foundations, New York: Foundation Center, 1999, p. 4.
PRI directory, which was published in 1995. Still, the field has undergone dramatic changes since the early 1990s: several new_including recently establishedPRI providers have developed formal programs or have made PRIs on an occasional basis; the number of PRI providers reporting PRI transactions of $\$ 10,000$ or more has grown (see below); and several major new PRI funders have emerged. Counterbalancing these positive developments, several foundations that reported PRI activity earlier in the decade were not active in the late 1990s. In a few cases, these funders had made major PRIs in response to specific national or regional initiatives and then indicated that they did not expect to continue the practice. ${ }^{4}$

\section{Trends in PRI Financing: 1998-1999}

The following trends analysis reviews the PRI activity of a sample of 133 leading PRI providers. A subset of the 192 foundations listed in the PRI Directory, these funders reported individual PRI transactions of $\$ 10,000$ or more, which are indexed in the Foundation Center's PRI database (see box on page iii.) Since many foundations do not make PRIs on an annual basis, the trends analysis examines a cumulative two-year period. In addition to providing a more representative sample of funders, the cumulative two-year snapshot also permits comparisons with trends identified in the Center's last analysis of PRI activity, which covered the period 1993-1994. ${ }^{5}$

\section{Dimensions of PRI Financing}

In the period 1998-1999, 133 leading PRI providers authorized 581 charitable loans and other PRI investments totaling nearly $\$ 427$ million (Table 1 ). PRI activity was not consistent across years. The level of PRI authorizations jumped from $\$ 148$ million in 1998 to nearly $\$ 279$ million in 1999.6 By contrast,

\footnotetext{
4. In the early to mid-1990s, a few large funders provided one-time support for the National Community Development Initiative (NCDI), a collaborative effort of major foundations, corporations, HUD, and local public and private organizations seeking to significantly increase urban community revitalization activities regionally and nationwide. NCDI's financing efforts were administered by the Local Initiatives Support Corporation (LISC) and the Enterprise Foundation.

5. See Mandler, C., The PRI Index: 500 Recent Foundation Charitable Loans and Investments, New York: Foundation Center, 1997.
} 
the number of PRIs authorized was higher in 1998. This finding suggests that, on average, PRI providers authorized much larger charitable loans and investments in 1999, following a period marked by extraordinary growth in foundation endowments. ${ }^{7}$

PRI financing by the leading providers has increased dramatically since the mid-1990s. During 1993-1994 (the last two-year period analyzed by the Foundation Center), a sample of 116 top providers authorized 388 program-related investments totaling $\$ 176.5$ million. During the five years since 1993-1994, the value of PRIs authorizations increased nearly two and a half times (141 percent) to $\$ 427$ million, while the number of PRIs increased by half (49.7 percent) to 581 (Figure 1). The sample of foundations reporting PRIs of $\$ 10,000$ or over grew a more modest 15 percent. (For information on the annual growth of PRIs for foundations in the PRI database, see Table A in "The Foundation Center's Historical PRI Database.").

TABLE 1. PRI Activity for Funders in the PRI Database Sample, 1998-1999*

\begin{tabular}{|c|c|c|c|}
\hline Year & $\begin{array}{c}\text { No. of } \\
\text { Foundations }\end{array}$ & $\begin{array}{c}\text { Dollar } \\
\text { Amount of PRIs }\end{array}$ & $\begin{array}{c}\text { No. } \\
\text { of PRIs }\end{array}$ \\
\hline 1998 & 89 & $\$ 148,067,104$ & 341 \\
\hline $1999^{1}$ & 82 & $278,860,757$ & 240 \\
\hline Total & 133 & $\$ 426,927,861$ & 581 \\
\hline
\end{tabular}

Source: PRI Directory, 2001.

*Based on PRI transactions of $\$ 10,000$ or more of a sample of larger PRI funders.

${ }^{1}$ Data incomplete or missing for a few foundations.
Profile of PRI Providers by Foundation Type and Size

In 1998-1999, nearly nine out of ten funders in the PRI database sample were independent foundations and they accounted for more than nine-tenths of all PRI dollars and more than four-fifths of PRIs (Table 2). Only 6 percent of the leading providers were corporate foundations, but they accounted for roughly one-in-seven PRIs (13.8 percent). By dollar amount, however, corporate funders provided only 5 percent of PRI financing. This suggests that, on average, their charitable loans and investments were smaller than the PRIs of independent foundations. Community foundations also represented 6 percent of the leading providers. Yet they were responsible for only 3 percent of the number of PRIs and 2 percent of the total dollar value of PRI financing. Compared with 19931994, community foundations' share of PRI financing has declined. Corporate foundations' share of PRI dollars has also decreased, but their share of number of PRIs has grown.

Although foundations in the sample represented all asset sizes, they tended to be larger relative to all foundations (Table 3). Six out of ten leading PRI providers (61 percent) held assets of $\$ 50$ million or more, and they accounted for 91 percent of new charitable loans and investments in 1998-1999. The endowments of PRI providers have grown

\footnotetext{
6. The total 1999 PRI amount for the PRI database sample includes PRIs authorized (vs. paid) in 1999 for those foundations that report new authorizations.

7. Foundation assets doubled between 1994 and 1998.
}

Figure 1. Growth of PRI Financing Between 1993-1994 and 1998-1999*

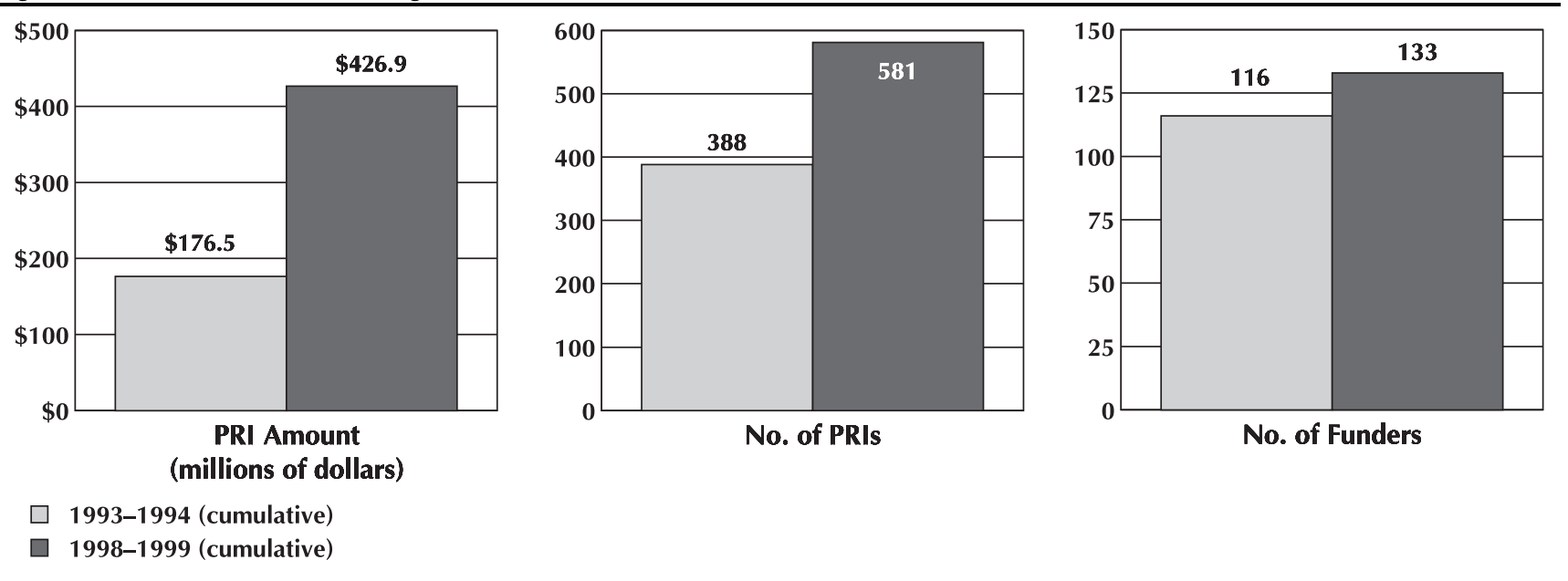

Source: PRI Directory, 2001

*Based on PRI transactions of $\$ 10,000$ or more of a sample of larger PRI funders. 
dramatically since the mid-1990s. Eighty-one PRI providers reported assets valued at $\$ 50$ million or more in 1999, compared with only 60 in 1994 . Moreover, fifteen PRI providers held assets of $\$ 1$ billion or over in 1999, more than double the number in 1994.
Still, among the very largest U.S. foundations, many do not have PRI programs. For example, only 15 of the 48 U.S. foundations with assets of $\$ 1$ billion or more reported PRI transactions of $\$ 10,000$ or more in 1998-1999. This finding suggests that asset size is not

\section{The Foundation Center's Historical PRI Database}

The Foundation Center's PRI database includes more than 2,100 individual records of program-related investments (PRIs) of \$10,000 or more made between 1990 and early 2000 by a diverse sample of larger independent, corporate, community, and operating foundations. These unique records provide the basis for detailed investigations of financing patterns. They are also a primary source of information for anyone seeking to find out who makes and who gets PRIs, and which fields benefit.

The sample of leading PRI funders-those making individual charitable loans and other charitable investments of $\$ 10,000$ and over-has increased since the early 1990s. For 1990-1992, the period analyzed in the Foundation Center's inaugural study of PRIs, the sample size was 100 funders. ${ }^{1}$ The number of larger funders increased to 116 for the period 1993-1994, which was examined in an updated trends report released in $1997 .{ }^{2}$ In the latest study period, $1998-1999$, the sample grew to 133 funders.

The Foundation Center's PRI database is modeled after its grants database. Individual PRI records include foundation name and state; recipient name, city, and state (or country); PRI amount; and year of authorization or payment. If available, additional information provided in the record includes loan term, interest rate charged, and a description of the project financed by the PRI. For purposes of retrieval and to facilitate trends analysis, individual PRI records are coded to track institutional or programmatic fields, recipient auspices, type of financial vehicle, type of support, and beneficiary groups. Institutional or programmatic codes were adapted from the National Taxonomy of Exempt Entities (NTEE), a comprehensive coding scheme developed by the

1. See Renz, L. et al., Program-Related Investments: A Guide to Funders and Trends, New York: Foundation Center, 1995.

2. See Mandler, C., The PRI Index: 500 Recent Foundation Charitable Loans and Investments, New York: Foundation Center, 1997.
National Center for Charitable Statistics to classify nonprofit activities, and used by the Foundation Center since 1989 to classify and track grants.

Records of PRI activity were gathered from lists of PRIs provided by funders, foundation publications, survey questionnaires, and IRS information returns (Form 990-PF) filed by foundations. A few leading PRI providers, especially those with cash flow loan programs, report only summary or cumulative PRI figures, instead of data on individual loans and their recipients. For lack of information from which to create discrete searchable records, the activities of those providers are not included in the PRI historical database. Nevertheless, those funders were researched, and entries describing their activities have appeared in both of the directories of PRI funders published by the Foundation Center.

Table A presents summary information on the PRI database sample from 1990 to 1999 . This database is available for fee-based searches performed by the Foundation Center's research staff.

TABLE A. PRI Activity for Funders in the PRI Database by Year Authorized*

\begin{tabular}{|c|c|c|c|}
\hline & $\begin{array}{c}\text { No. of } \\
\text { Foundations }\end{array}$ & $\begin{array}{c}\text { Dollar } \\
\text { Amount of PRIs } \\
\end{array}$ & $\begin{array}{c}\text { No. } \\
\text { of PRIs }\end{array}$ \\
\hline 1990 & 57 & $91,919,366$ & 161 \\
\hline 1991 & 76 & $130,028,751$ & 202 \\
\hline 1992 & 74 & $117,714,091$ & 181 \\
\hline 1993 & 93 & $103,655,127$ & 215 \\
\hline 1994 & 69 & $72,893,253$ & 173 \\
\hline 1995 & 69 & $94,530,363$ & 180 \\
\hline 1996 & 62 & $76,575,398$ & 197 \\
\hline 1997 & 70 & $143,868,571$ & 268 \\
\hline 1998 & 89 & $148,067,104$ & 341 \\
\hline $1999^{1}$ & 82 & $278,860,757$ & 240 \\
\hline & & $\$ 1,258,112,781$ & 2,158 \\
\hline \multicolumn{4}{|c|}{$\begin{array}{l}\text { Source: PRI Directory, } 2001 \text {. } \\
\text { *Based on PRI transactions of } \$ 10,000 \text { or more of a sample of larger } \\
\text { PRI funders. } \\
{ }^{1} \text { Data incomplete or missing for a few foundations. }\end{array}$} \\
\hline
\end{tabular}


the principal determinant for making PRIs. ${ }^{8}$ Even foundations with significant resources, and therefore greater capacity to manage loans and charitable investments, have not opted to do so despite extraordinary growth in their endowments in the past five years.

The number of smaller foundations in the PRI database has not grown since 1993-1994. Still, 52 foundations with assets of less than $\$ 50$ million made PRIs totaling nearly \$38 million in 1998-1999 and were responsible for one-third of the total number of PRIs in the sample.

\section{PRI Support for Organizations vs. Investments in Charitable Use Property}

The vast majority of foundations use PRIs to support recipient organizations (including their grantees) through direct lending, guaranteeing loans, lending to loan funds, capitalizing development banks and venture capital funds, or by making equity investments. In contrast, a small number of foundationssix in the sample of 133-use PRIs to acquire or improve property held for charitable purposes (referred to as "charitable use property"). In these cases, property is either permanently held by the

8. For a discussion about incentives and disincentives to PRI making, see "Capturing the Experience of Funders and Recipients" in Program-Related Investments: A Guide to Funders and Trends, New York: Foundation Center, 1995. foundation, with space donated or leased to nonprofit organizations at below market rates, or held temporarily and given away as a grant or sold to a nonprofit or a government agency. Figure 2 shows that of the nearly $\$ 427$ million authorized in 1998-1999, $\$ 345.9$ million (81 percent) financed 561 PRI transactions involving a borrower or investee and subject to repayment, while the remaining $\$ 81$ million (19 percent) consisted of investments in charitable use property.

Because their purposes and uses are so distinct, PRIs in the form of charitable use assets are excluded from the following discussion of trends in financing. The analysis and accompanying data tables focus solely on PRI providers that made charitable loans or investments directly supporting other organizations. Nevertheless, investing in charitable use property is an important activity for a few foundations.

Table 4 provides brief information on the leading funders in this volume reporting charitable use assets. Among the six funders listed, the Richard King Mellon Foundation (PA) was by far the most active. In 1998-1999, the foundation invested $\$ 64.3$ million in land conservation through its American Land Conservation Program. The other principal funders reporting charitable use assets included the Presbyterian Health Foundation (OK), which supported construction of a medical research facility through its Research Park Project, and the Meadows Foundation (TX), which has acquired land and houses

TABLE 2. PRI Financing by Foundation Type, 1998-1999*

\begin{tabular}{lcrrrrr}
\hline Foundation Type & No. of Foundations & \multicolumn{1}{c}{$\%$} & Dollar Amount of PRIs & \multicolumn{1}{c}{$\%$} & No. of PRIs & \% \\
\hline Independent & 117 & 88.0 & $\$ 396,335,330$ & 92.8 & 482 & 83.0 \\
Corporate & 8 & 6.0 & $21,548,003$ & 5.0 & 80 & 13.8 \\
Community & 8 & 6.0 & $9,044,528$ & 2.1 & 19 & 3.3 \\
\multicolumn{1}{c}{ Total } & $\mathbf{1 3 3}$ & $\mathbf{1 0 0 . 0}$ & $\mathbf{\$ 4 2 6 , 9 2 7 , 8 6 1}$ & $\mathbf{1 0 0 . 0}$ & $\mathbf{5 8 1}$ & $\mathbf{1 0 0 . 0}$ \\
\hline
\end{tabular}

Source: PRI Directory, 2001.

*Based on PRI transactions of $\$ 10,000$ or more made in 1998 and 1999 by a sample of 133 larger PRI funders.

TABLE 3. Distribution of PRI Funders in 1998-1999 by Asset Size*

\begin{tabular}{|c|c|c|c|c|c|c|}
\hline Asset Range $^{1}$ & No. of Foundations & $\%$ & Dollar Amount of PRIs & $\%$ & No. of PRIs & $\%$ \\
\hline \$1 billion+ & 15 & 11.3 & $\$ 238,959,169$ & 56.0 & 87 & 15.0 \\
\hline$\$ 250$ million-\$1 billion & 28 & 21.1 & $105,010,881$ & 24.6 & 143 & 24.6 \\
\hline$\$ 50$ million-\$250 million & 38 & 28.6 & $45,272,407$ & 10.6 & 157 & 27.0 \\
\hline \$10 million-\$50 million & 33 & 24.8 & $26,679,176$ & 6.2 & 77 & 13.3 \\
\hline Under \$10 million & 19 & 14.3 & $11,006,228$ & 2.6 & 117 & 20.1 \\
\hline Total & 133 & 100.0 & $\$ 426,927,861$ & 100.0 & 581 & 100.0 \\
\hline
\end{tabular}

Source: PRI Directory, 2001.

*Based on PRI transactions of \$10,000 or more made in 1998 and 1999 by a sample of 133 larger PRI funders. Due to rounding, figures may not add up.

${ }^{1}$ Based on market value of assets reported to the Foundation Center as of January 2001. Fiscal year for most foundations was 1999. 
in an historic district of downtown Dallas and is restoring and preserving these properties.

\section{Trends in PRI Support for Organizations}

Of the 133 foundations in the sample, 129 made charitable loans or other investments involving recipients (including two funders that also invested in charitable use property). These transactions totaled

FIGURE 2. Analysis of PRI Activity by Assets Loaned or Invested vs. Assets Held as Charitable Use Property, 1998-1999*

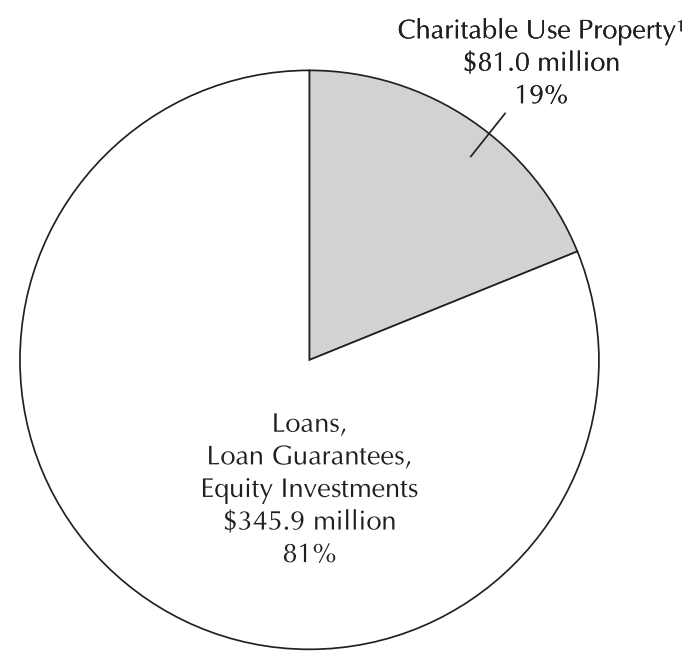

Percent of PRI Dollars

Total PRI Activity $=\$ \mathbf{4 2 6 . 9}$ million

Source: PRI Directory, 2001.

*Based on PRI transactions of \$10,000 or more made in 1998 and 1999 by a sample of 133 larger PRI funders.

${ }^{1}$ Program-related investments in properties that are used for charitable purposes.
$\$ 345.9$ million over the period 1998-1999. This analysis profiles PRI providers and recipients and examines PRI support by size of individual PRIs, geographic focus, programmatic focus, major purpose, type of financial vehicle, and population group served.

\section{Large vs. Small PRI Providers}

Although 129 funders made charitable loans or other PRI transactions in 1998-1999, the largest providers were responsible for a disproportionate share of the total financing. The top ten funders provided 66.5 percent of all distributions, while the top 35-those authorizing at least $\$ 1$ million in new financing during the two-year period-accounted for nearly 91 percent of the total funds (Table 5).

Compared with 1993-1994, the listing of top ten providers reveals very dramatic changes. Three of the largest funders-the Lynde and Harry Bradley Foundation (WI), California Endowment (CA), and Marty and Dorothy Silverman Foundation (NY) - were new to the top ten in 1998-1999. The seven remaining providers all experienced changes in their ranking. The Pew Charitable Trusts (PA) displaced the Ford Foundation as the top-ranked PRI provider, while Ford slipped to fourth place. The David and Lucile Packard Foundation (CA), which ranked third in 1993-1994, advanced to second place, displacing the John D. and Catherine T. MacArthur Foundation, which ranked fifth. The Bradley Foundation became the third largest PRI provider in 1998-1999 — up from thirty-third in 1993-1994-although it has made PRIs only on a limited basis (in the areas of community improvement and public/ society benefit). The sixth-ranked

TABLE 4. PRI Funders Investing in Charitable Use Property, 1998-1999*

\begin{tabular}{|c|c|c|c|c|}
\hline Foundation & State & $\begin{array}{l}\text { Dollar Amount } \\
\text { of PRIs }\end{array}$ & Type of Property & Programmatic Purpose \\
\hline Richard King Mellon Foundation & PA & $\$ 64,341,754$ & Land & $\begin{array}{l}\text { American Land Conservation } \\
\text { Program }\end{array}$ \\
\hline Presbyterian Health Foundation & $\mathrm{OK}$ & $7,392,034$ & Research Park Project_building & Medical research \\
\hline Meadows Foundation & TX & $5,743,680$ & Historic district_land and houses & Historic preservation \\
\hline Parnell Family Foundation & WA & $2,556,529$ & Building & $\begin{array}{l}\text { For construction of buildings to } \\
\text { lease to Seventh Day Adventist } \\
\text { Church }\end{array}$ \\
\hline $\begin{array}{l}\text { Robert S. and Grayce B. Kerr } \\
\text { Foundation }\end{array}$ & WY & 777,308 & Artwork & $\begin{array}{l}\text { Lending art to National Museum } \\
\text { of Wildlife Art }\end{array}$ \\
\hline Eddy Foundation & $\mathrm{CA}$ & 225,047 & Land & Wildlife preservation \\
\hline Total & & $\$ 81,036,352$ & & \\
\hline
\end{tabular}

Source: PRI Directory, 2001.

*Based on PRI transactions of $\$ 10,000$ or more made in 1998 and 1999 by a sample of 133 larger PRI funders.

${ }^{1} \mathrm{PRI}$ amount represents charitable distributions reported during the period and not the total value of the property. 
California Endowment is a new PRI provider. One of the largest "new health" foundations, the Endowment began operations in 1996 and made its first PRI in 1999. Like the Bradley Foundation, the Endowment makes PRIs on an occasional basis and does not have a formal PRI program.

The amount of PRI distributions of several of the top ten funders has soared since 1993-1994. For example, the Pew Trusts' authorizations totaled \$42.5 million in 1998-1999, up from $\$ 7.5$ million five years ago. The Packard Foundation's authorizations climbed to $\$ 39.6$ million, up from $\$ 8$ million in 1993-1994. The Prudential Foundation, which displaced Metropolitan Life Foundation as the top corporate PRI provider, distributed 32 loans totaling $\$ 11.2$ million in 1998-1999, up from two loans totaling \$3 million five years ago. The Cleveland Foundation, which ranked first among community foundations, distributed nearly $\$ 7.9$ million in 1998-1999, up from \$2.3 million in 1993-1994.

TABLE 5. 35 Largest PRI Providers, 1998-1999*

\begin{tabular}{|c|c|c|c|c|c|}
\hline & Foundation & State & $\begin{array}{c}\text { Dollar Amount } \\
\text { of PRIs }\end{array}$ & $\%$ & No. of PRIs \\
\hline 1. & Pew Charitable Trusts & PA & $\$ 42,500,000$ & 12.3 & 5 \\
\hline 2. & David and Lucile Packard Foundation & CA & $39,619,888$ & 11.5 & 11 \\
\hline 3. & Lynde and Harry Bradley Foundation & $\mathrm{Wl}$ & $36,000,000$ & 10.4 & 2 \\
\hline 4. & Ford Foundation & NY & $28,000,000$ & 8.1 & 18 \\
\hline 5. & John D. and Catherine T. MacArthur Foundation & IL & $23,099,000$ & 6.7 & 21 \\
\hline 6. & California Endowment & CA & $20,000,000$ & 5.8 & 1 \\
\hline 7. & Marty and Dorothy Silverman Foundation & NY & $13,202,500$ & 3.8 & 10 \\
\hline 8. & Prudential Foundation & $\mathrm{NJ}$ & $11,184,048$ & 3.2 & 32 \\
\hline 9. & Layne Foundation & $\mathrm{CA}$ & $8,446,439$ & 2.4 & 14 \\
\hline 10. & Cleveland Foundation & $\mathrm{OH}$ & $7,888,000$ & 2.3 & 10 \\
\hline 11. & George Gund Foundation & $\mathrm{OH}$ & $6,864,888$ & 2.0 & 5 \\
\hline 12. & Fannie Mae Foundation & DC & $6,845,000$ & 2.0 & 29 \\
\hline 13. & C.I.O.S. & TX & $5,946,384$ & 1.7 & 31 \\
\hline 14. & Otto Bremer Foundation & $\mathrm{MN}$ & $5,818,500$ & 1.7 & 28 \\
\hline 15. & F. B. Heron Foundation & NY & $5,500,000$ & 1.6 & 15 \\
\hline 16. & Conrad N. Hilton Foundation & NV & $5,000,000$ & 1.4 & 5 \\
\hline 17. & McKnight Foundation & $\mathrm{MN}$ & $5,000,000$ & 1.4 & 1 \\
\hline 18. & W. K. Kellogg Foundation & MI & $4,850,000$ & 1.4 & 4 \\
\hline 19. & AVI CHAI Foundation & NY & $4,800,000$ & 1.4 & 7 \\
\hline 20. & Walton Family Foundation & $\mathrm{AR}$ & $4,500,030$ & 1.3 & 2 \\
\hline 21. & Righteous Persons Foundation & $\mathrm{CA}$ & $3,880,000$ & 1.1 & 1 \\
\hline 22. & Development Credit Fund & $\mathrm{MD}$ & $2,953,550$ & 0.9 & 37 \\
\hline 23. & T. L. L. Temple Foundation & TX & $2,600,000$ & 0.8 & 2 \\
\hline 24. & Abell Foundation & MD & $2,490,000$ & 0.7 & 10 \\
\hline 25. & James Hervey Johnson Charitable Educational Trust & $\mathrm{CA}$ & $2,488,979$ & 0.7 & 4 \\
\hline 26. & Tikvah Fund & NY & $2,370,298$ & 0.7 & 3 \\
\hline 27. & Whitaker Foundation & VA & $1,945,755$ & 0.6 & 1 \\
\hline 28. & Media Development Loan Fund & NY & $1,940,187$ & 0.6 & 20 \\
\hline 29. & Joe W. \& Dorothy Dorsett Brown Foundation & LA & $1,659,385$ & 0.5 & 10 \\
\hline 30. & Faith Foundation & OR & $1,325,000$ & 0.4 & 3 \\
\hline 31. & Blandin Foundation & $\mathrm{MN}$ & $1,300,000$ & 0.4 & 1 \\
\hline 32. & Winthrop Rockefeller Foundation & $\mathrm{AR}$ & $1,155,000$ & 0.3 & 1 \\
\hline 33. & Metropolitan Life Foundation & NY & $1,098,955$ & 0.3 & 4 \\
\hline 34. & Clark Foundation & NY & $1,000,000$ & 0.3 & 1 \\
\hline & Y \& H Soda Foundation & CA & $1,000,000$ & 0.3 & 1 \\
\hline \multicolumn{3}{|c|}{ Subtotal } & $\$ 314,271,786$ & 90.9 & 350 \\
\hline \multicolumn{3}{|c|}{ All other foundations } & $\$ 31,619,723$ & 9.1 & 211 \\
\hline \multicolumn{3}{|c|}{ Total } & $\$ 345,891,509$ & 100.0 & 561 \\
\hline
\end{tabular}

Source: PRI Directory, 2001.

*Based on PRI transactions of \$10,000 or more made in 1998 and 1999 by a sample of 129 larger PRI funders. Excludes PRI distributions for charitable use property. 1999 data is incomplete for a few providers. 
Cleveland made ten PRIs in the latest two-year period, compared with three five years ago.

Other funders who were ranked among the largest in both periods and whose PRI activity increased substantially in 1998-1999 included the Silverman Foundation (noted above), the Layne Foundation (CA), the George Gund Foundation $(\mathrm{OH})$, C.I.O.S. (TX), and the Otto Bremer Foundation (MN). Funders new to the list of the largest PRI makers include well established foundations, such as the W. K. Kellogg Foundation (MI), Conrad Hilton Foundation (NV), Fannie Mae Foundation (DC), and Abell Foundation (MD); and also several foundations formed in the 1990s or late 1980s, including the California Endowment, F.B. Heron Foundation (NY), Walton Family Foundation (AR), Righteous Persons Foundation (CA), Development Credit Fund (MD), and Media Development Loan Fund (NY).

The number of larger PRI providers has greatly expanded over the past five years. Table 6 shows that in 1998-1999, eight foundations distributed at least $\$ 10$ million in loans and other charitable investments and 35 foundations distributed at least \$1 million. In contrast, in 1993-1994, only three foundations reached the $\$ 10$ million threshold, while just 20 met the $\$ 1$ million criteria. These larger providers represented more than one-fourth of the sample (27 percent) in the latest period, compared with roughly one-sixth (18 percent) five years earlier.

The number of providers in the middle distribution ranges has also increased. Fifty-three foundations (41 percent of the sample) distributed between $\$ 250,000$ and \$1 million in PRIs in 1998-1999, up from 35 foundations (33 percent) in 1993-1994.

The number and share of providers making PRI distributions totaling less than $\$ 250,000$ has declined. Foundations authorizing less than \$250,000 in PRI distributions represented less than one-third of the sample of all providers in 1998-1999 (32 percent). Five years earlier, they accounted for one-half of providers.

\section{Geographic Distribution}

\section{State and Regional Distribution of PRI Providers}

PRI providers in the sample were located in 31 states and the District of Columbia. Nevertheless, 103 providers in 15 states provided the vast majority (96.5 percent) of PRI dollars distributed to recipients in 1998-1999, and 66 funders in just five states provided nearly three-fourths (72.6 percent) of all PRI support (Table 7).

California led the nation by amount of PRI financing. With its 18 PRI makers, led by the Packard Foundation, the state provided nearly 23 percent of all PRI dollars (\$78.3 million), yet less than 9 percent of the number of PRIs (50). New York, which towered above all other states in PRI financing in the early 1990s (due largely to the preeminence of the Ford Foundation), ranked second by PRI amount (\$60.6 million or 17.5 percent) in 1998-1999. Still, it matched California by number of providers (18), and distributed nearly twice as many PRIs (99 or 17.6 percent). Pennsylvania ranked third by PRI amount ( $\$ 48.1$ million) and fourth by number of providers (12). Wisconsin, with only four PRI funders in the state, ranked fourth by PRI amount, due mainly to the Bradley Foundation's exceptionally large PRIs. Illinois ranked fifth by PRI amount (\$27.7 million), but it placed second by number of PRIs (56), and third by number of PRI providers (14). In the early 1990s, Illinois ranked second to New York among the top states, largely due to the significant activity of the MacArthur Foundation.

TABLE 6. Distribution of PRI Providers by Range of PRI Financing, 1998-1999*

\begin{tabular}{|c|c|c|c|c|c|c|}
\hline PRI Activity Range & $\begin{array}{c}\text { No. of } \\
\text { Foundations }\end{array}$ & $\%$ & No. of PRIs & $\%$ & $\begin{array}{c}\text { Dollar Amount } \\
\text { of PRIs }\end{array}$ & $\%$ \\
\hline \$25 million+ & 4 & 3.1 & 36 & 6.4 & $\$ 146,119,888$ & 42.2 \\
\hline \$10 million-\$25 million & 4 & 3.1 & 64 & 11.4 & $67,485,548$ & 19.5 \\
\hline \$5 million-\$10 million & 9 & 7.0 & 138 & 24.6 & $57,309,211$ & 16.6 \\
\hline \$1 million-\$5 million & 18 & 14.0 & 112 & 20.0 & $43,357,139$ & 12.5 \\
\hline$\$ 500,000-\$ 1$ million & 31 & 24.0 & 93 & 16.6 & $20,013,260$ & 5.8 \\
\hline$\$ 250,000-\$ 500,000$ & 22 & 17.1 & 62 & 11.1 & $7,787,479$ & 2.3 \\
\hline Under $\$ 250,000$ & 41 & 31.8 & 56 & 10.0 & $3,818,984$ & 1.1 \\
\hline Total & 129 & 100.0 & 561 & 100.0 & $\$ 345,891,509$ & 100.0 \\
\hline
\end{tabular}

Source: PRI Directory, 2001.

*Based on PRI transactions of \$10,000 or more made in 1998 and 1999 by a sample of 129 larger PRI funders. Excludes PRI distributions for charitable use property. 
TABLE 7. Top 15 States by PRIs Reported, 1998-1999*

\begin{tabular}{|c|c|c|c|c|c|c|}
\hline State & $\begin{array}{l}\text { No. of } \\
\text { Funders }\end{array}$ & s $\%$ & $\begin{array}{l}\text { Dollar } \\
\text { Amount } \\
\text { of PRIs }\end{array}$ & $\%$ & $\begin{array}{c}\text { No. of } \\
\text { PRIs }\end{array}$ & $\%$ \\
\hline California & 18 & 14.0 & $\$ 78,314$ & 22.6 & 50 & 8.9 \\
\hline New York & 18 & 14.0 & 60,573 & 17.5 & 99 & 17.6 \\
\hline Pennsylvania & 12 & 9.3 & 48,145 & 13.9 & 25 & 4.5 \\
\hline Wisconsin & 4 & 3.1 & 36,750 & 10.6 & 9 & 1.6 \\
\hline Illinois & 14 & 10.9 & 27,684 & 8.0 & 56 & 10.0 \\
\hline Ohio & 4 & 3.1 & 15,199 & 4.4 & 19 & 3.4 \\
\hline Minnesota & 4 & 3.1 & 12,760 & 3.7 & 37 & 6.6 \\
\hline New Jersey & 2 & 1.6 & 11,816 & 3.4 & 34 & 6.1 \\
\hline Texas & 5 & 3.9 & 10,486 & 3.0 & 40 & 7.1 \\
\hline District of Columbia & 10 & 7.8 & 8,593 & 2.5 & 47 & 8.4 \\
\hline Maryland & 4 & 3.1 & 5,676 & 1.6 & 49 & 8.7 \\
\hline Arkan & 2 & 1.6 & 5,655 & 1.6 & 3 & 0.5 \\
\hline Michigan & 2 & 1.6 & 5,050 & 1.5 & 5 & 0.9 \\
\hline Nevada & 1 & 0.8 & 5,000 & 1.4 & 5 & 0.9 \\
\hline Oregon & 3 & 2.3 & 1,975 & 0.6 & 7 & 1.2 \\
\hline Subtotal & 103 & 79.8 & $\$ 333,676$ & 96.5 & 485 & 86.5 \\
\hline All other states & 26 & 20.2 & $\$ 12,216$ & 3.5 & 76 & 13.5 \\
\hline Total & 1291 & 100.0 & $\$ 345,892$ & 100.0 & 561 & 100.0 \\
\hline
\end{tabular}

Source: PRI Directory, 2001.

*Based on PRI transactions of \$10,000 or more made in 1998 and 1999 by a sample of 129 larger PRI funders. Excludes PRI distributions for charitable use property. Dollars in thousands.

Figure 3 shows the regional distribution of PRI financing in 1998-1999. Foundations in the Northeast led the country, providing more than one-third (35.3 percent) of PRI dollars. Following the Northeast, foundations in the Midwest and West provided the second and third largest shares of PRI funds (28.4 percent and 25.8 percent, respectively). Foundations in the South accounted for a modest 11.1 percent of total funds.

\section{State and Regional Distribution of PRI Recipients}

States in which foundations provided the largest share of PRI funding generally also attracted the largest share of PRI dollars (Table 8). This finding reflects either the localized focus of most foundation support and/or the concentration of borrowers, especially financial intermediaries, in particular states. Exceptions included Virginia, Maryland, Mississippi, Florida, and Kentucky. Although they did not report many large PRI providers, these states received relatively large PRI amounts, directed either to intermediaries or to local or regional development agencies, community groups, or larger institutions (such as universities). In addition, Wisconsin, one of the top-ranked funder states, also received far more in PRI financing than its funders provided. Wisconsin's distributions in 19981999 totaled \$36.7 million, while organizations in
FIGURE 3. Distribution of PRI Financing by Region, 1998-1999*

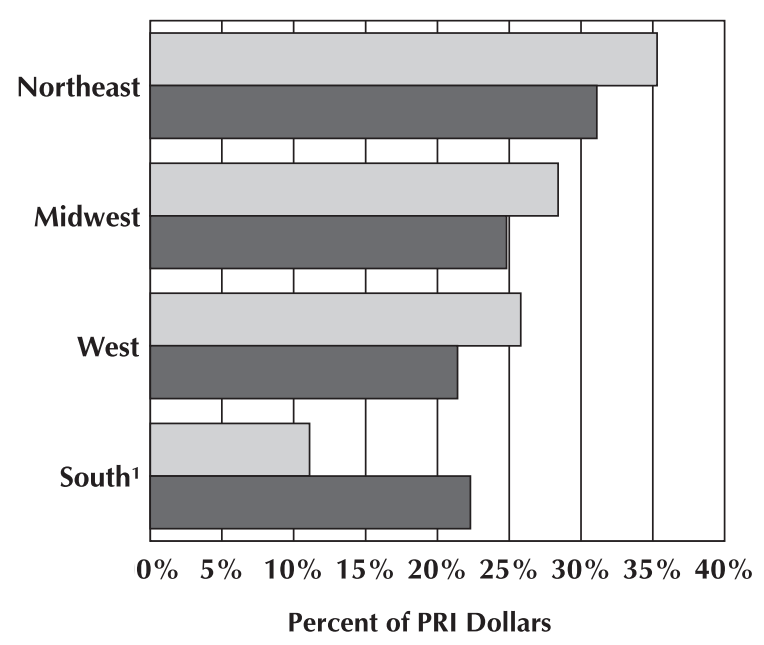

PRI Dollars Provided

PRI Dollars Received

Source: PRI Directory, 2001.

*Based on PRI transactions of \$10,000 or more made in 1998 and 1999 by a sample of 129 larger PRI funders. Excludes PRI distributions for charitable use property.

Includes support for national and international organizations located in and around Washington, DC.

the state received $\$ 43.4$ million, placing it second to California by PRI amount received. Top-ranked states whose funders distributed far more proportionally than recipients in those states took in included Illinois and New York, which are home to prominent national and international funders (especially MacArthur and Ford), followed by California ${ }^{9}$ and Pennsylvania.

Figure 3 shows that, by region, recipients in the Northeast received the largest share of PRI dollars, followed by the Midwest, the South, and the West. PRI recipients in the South received more than 22 percent of PRI financing, double the share provided by foundations in the region. Several national funders provided PRIs for rural development and business and job promotion in economically disadvantaged areas of the South. Other foundations provided PRIs to national and international agencies based in or near Washington, DC, such as the Nature Conservancy

9. Since the early 1990s, California has changed its status from being a net importer of PRIs (from national funders in other states) to a net exporter. In 1998-1999, California organizations ranked first by amount of PRI support received ( $\$ 64.9$ million or 19 percent). Still, this amount was less than the $\$ 78.3$ million distributed by California providers. By contrast, in 1990-1991, California recipients took in $\$ 42.4$ million, while California foundations distributed only $\$ 27.9$ million in PRIs. These changes reflect the dramatic growth of foundation resources in California in the 1990s. As California foundations have grown, a few, such as the Packard Foundation, have developed a regional, national, or even international funding perspective. 
and the Women's Capital Corporation. Some of the funds invested in national organizations specifically targeted projects, such as land conservation, in individual states.

\section{Domestic vs. International PRI Financing}

Most PRIs were invested with U.S. organizations. As shown in Table 9, only 29 PRIs in 1998-1999 totaling $\$ 9.4$ million (2.7 percent) represented loans or investments with overseas recipients. Leaders in cross-border financing included Ford and MacArthur, which have long been active overseas, as well as the

TABLE 8. Top 15 States by PRIs Received, 1998-1999*

\begin{tabular}{|c|c|c|c|c|}
\hline State & $\begin{array}{c}\text { Dollar Amount } \\
\text { of PRIs }\end{array}$ & $\%$ & $\begin{array}{l}\text { No. of } \\
\text { PRIs }\end{array}$ & $\%$ \\
\hline California & $\$ 64,919$ & 19.3 & 59 & 11.1 \\
\hline Wisconsin & 43,428 & 12.9 & 13 & 2.4 \\
\hline New York & 43,210 & 12.8 & 46 & 8.6 \\
\hline Pennsylvania & 42,771 & 12.7 & 23 & 4.3 \\
\hline Ohio & 14,949 & 4.4 & 19 & 3.6 \\
\hline Virginia & 14,539 & 4.3 & 10 & 1.9 \\
\hline Minnesota & 12,457 & 3.7 & 30 & 5.6 \\
\hline Maryland & 11,075 & 3.3 & 58 & 10.9 \\
\hline District of Columbia & 10,605 & 3.2 & 30 & 5.6 \\
\hline New Jersey & 10,599 & 3.1 & 33 & 6.2 \\
\hline Texas & 8,971 & 2.7 & 25 & 4.7 \\
\hline Illinois & 8,409 & 2.5 & 40 & 7.5 \\
\hline Mississippi & 5,470 & 1.6 & 8 & 1.5 \\
\hline Florida & 5,171 & 1.5 & 23 & 4.3 \\
\hline Kentucky & 5,159 & 1.5 & 11 & 2.1 \\
\hline Subtotal & $\$ 301,732$ & 89.7 & 428 & 80.5 \\
\hline All other states & $\$ 34,759$ & 10.3 & 104 & 19.5 \\
\hline Total $^{1}$ & $\$ 336,491$ & 100.0 & 532 & 100.0 \\
\hline
\end{tabular}

Source: PRI Directory, 2001.

*Based on PRI transactions of $\$ 10,000$ or more made in 1998 and 1999 by a sample of 129 larger PRI funders. Excludes PRI distributions for charitable use property. Dollars in thousands.

${ }^{1}$ Excludes 29 PRIs made to overseas organizations.

TABLE 9. Domestic and International PRIs, 1998-1999*

\begin{tabular}{|c|c|c|c|c|}
\hline Focus of PRIs & $\begin{array}{c}\text { Dollar Amount } \\
\text { of PRIs } \\
\end{array}$ & $\%$ & $\begin{array}{c}\text { No. of } \\
\text { PRIs }\end{array}$ & $\%$ \\
\hline Domestic & $\$ 331,202$ & 95.8 & 521 & 92.9 \\
\hline International & 14,689 & 4.2 & 40 & 7.2 \\
\hline Overseas Recipients & 9,400 & 2.7 & 29 & 5.2 \\
\hline U.S.-Based Recipients & 5,289 & 1.5 & 11 & 2.0 \\
\hline Total & $\$ 345,891$ & 100.0 & 561 & 100.0 \\
\hline
\end{tabular}

Source: PRI Directory, 2001.

*Based on PRI transactions of \$10,000 or more made in 1998 and 1999 by a sample of 129 larger PRI funders. Excludes PRI distributions for charitable use property. Dollar figures in thousands; due to rounding, figures may not add up.
Media Development Loan Fund, a new (est. 1993) Soros-related foundation that distributed nearly $\$ 2$ million in 1998-1999 to fledgling independent media organizations in Central Europe and Russia. With the exception of the Fund, most support overseas financed microcredit and microenterprise development. Examples of major recipients included the Kenya Women Finance Trust Limited, CAME-Los Emprendedores Trust in Mexico, and Bhartiya Samruddi Investments and Consulting in India.

An additional 11 PRls totaling $\$ 5.3$ million (1.5 percent) were made to U.S.-based organizations in support of international programs, with an emphasis on sustainable development and environmental protection. Examples of recipients included Accion International and the Rainforest Alliance.

\section{Types of PRI Financial Vehicles}

PRI transactions include charitable loans, equity investments, and other types of financial vehicles or "tools." Table 10 shows the distribution of PRI dollars and number of PRIs by type of vehicle. Loans represented nearly 50 percent of classifiable PRI dollars, but more than 68 percent of PRIs. Of the 384 loans coded for type of vehicle in the PRI database, 33 were identified specifically as bridge loans or shortterm financing. Only a handful of PRIs (13) were found to be loan guarantees or lines of credit. Similarly, relatively few PRIs (8) took the form of equity investments. Unfortunately, nearly three-tenths of PRIs (156) could not be classified by type of vehicle for lack of descriptive information provided in foundation source documents, especially 990-PF tax returns. These PRIs represented nearly half (46 percent) of total PRI dollars. Based on findings from research in the mid-1990s, it is likely that a large majority of these unspecified PRIs were loans.

\section{Size of Individual PRIs}

Although many local PRI funders tailor their loan programs to provide small amounts - especially for interim financing and emergency loans-Table 11 shows that close to two-thirds (64 percent) of the PRIs invested with recipients were in amounts of at least $\$ 100,000$, and these larger PRIs accounted for 98 percent of PRI financing. The most typical PRIs were for amounts between $\$ 100,000$ and $\$ 500,000$. More than 37 percent of PRIs (210) fell into that size category. Looking at the largest PRIs, 91 (16 percent) were in amounts of at least $\$ 1$ million, including 13 PRIs of $\$ 5$ million or more. 
The sample confirms that PRIs are on average far larger in dollar value than foundation grants. For example, of the 108,000 grants of $\$ 10,000$ or more reported in the Foundation Center's grants database for 1999 , less than 2.0 percent were valued at $\$ 1$ million or over, compared with 16 percent of PRIs, and less than 21 percent of grants were in amounts of at least $\$ 100,000$, compared with 64 percent of PRIs.

\section{Programmatic Focus}

The Foundation Center reports broad funding trends within ten broad major subject divisions and 24 field areas. These institutional/subject classifications derive from the National Taxonomy of Exempt Entities. The individual PRI records included in this sample may be

TABLE 10. Types of PRI Financial Vehicles, 1998-1999*

\begin{tabular}{|c|c|c|c|c|}
\hline $\begin{array}{l}\text { Type of Financial } \\
\text { Vehicle }\end{array}$ & $\begin{array}{c}\text { Dollar Amount } \\
\text { of PRIs }\end{array}$ & $\%$ & $\begin{array}{l}\text { No. of } \\
\text { PRIs }\end{array}$ & $\%$ \\
\hline \multicolumn{5}{|l|}{ Loans } \\
\hline Bridge Loans & $\$ 7,525,548$ & 2.2 & 33 & 5.9 \\
\hline All Other Loans & $164,509,374$ & 47.6 & 351 & 62.6 \\
\hline Subtotal & $\$ 172,034,922$ & 49.7 & 384 & 68.4 \\
\hline Loan Guarantees & $4,054,888$ & 1.2 & 7 & 1.2 \\
\hline Lines of Credit & $4,476,038$ & 1.3 & 6 & 1.1 \\
\hline Equity Investments & $5,566,323$ & 1.6 & 8 & 1.4 \\
\hline PRIs, Unspecified & $159,759,338$ & 46.2 & 156 & 27.8 \\
\hline Total & $\$ 345,891,509$ & 100.0 & 561 & 100.0 \\
\hline
\end{tabular}

Source: PRI Directory, 2001.

*Based on PRI transactions of \$10,000 or more made in 1998 and 1999 by a sample of 129 larger PRI funders. Excludes PRI distributions for charitable use property. Due to rounding, figures may not add up.

TABLE 11. Distribution of PRIs by Size Range, 1998-1999*

\begin{tabular}{|c|c|c|c|c|}
\hline PRI Range & $\begin{array}{l}\text { No. of } \\
\text { PRIs }\end{array}$ & $\%$ & $\begin{array}{c}\text { Dollar Amount } \\
\text { of PRIs }\end{array}$ & $\%$ \\
\hline$\$ 5$ million and over & 13 & 2.3 & $\$ 136,400$ & 39.4 \\
\hline \$1 million-under \$5 million & 78 & 13.9 & 119,348 & 34.5 \\
\hline$\$ 500,000$-under $\$ 1$ million & 59 & 10.5 & 35,285 & 10.2 \\
\hline$\$ 100,000$-under $\$ 500,000$ & 210 & 37.4 & 46,520 & 13.4 \\
\hline$\$ 50,000$-under $\$ 100,000$ & 77 & 13.7 & 4,998 & 1.4 \\
\hline$\$ 25,000-$ under $\$ 50,000$ & 67 & 11.9 & 2,350 & 0.7 \\
\hline$\$ 10,000$-under $\$ 25,000$ & 57 & 10.2 & 990 & 0.3 \\
\hline Total & 561 & 100.0 & $\$ 345,892$ & 100.0 \\
\hline
\end{tabular}

Source: PRI Directory, 2001.

*Based on PRI transactions of \$10,000 or more made in 1998 and 1999 by a sample of 129 larger PRI funders. Excludes PRI distributions for charitable use property. Dollar figures in thousands; due to rounding figures may not add up. accessed by subject in the "Index to PRIs by Subject" section of this volume.

Community Development and Housing. The community development field —encompassing a wide range of activities from housing development to neighborhood revitalization in large urban centers to small business promotion in rural communitiesrepresents the largest area of PRI financing (Figure 4). Two-fifths of new investment dollars, or \$139.4 million, and a slightly smaller share of PRIs ( 37 percent) financed community development and housing development in 1998-1999. Investments in community development projects totaled $\$ 109$ million, while investments earmarked specifically for housing and home ownership totaled \$30.4 million.

Since the early 1990s, the share of PRI financing for community/economic development has stayed at or above three-tenths, while the share for housing has steadily declined. In 1998-1999, housing and home ownership accounted for less than 9 percent of PRI dollars (\$30.4 million), down from 18 percent in 1993-1994 and 20 percent in 1992. Housing's share of the number of PRIs dropped from 21 percent in the early 1990 s to 13 percent in 1998-1999. In contrast, community development's share of PRIs has increased from one-fifth to nearly one-quarter.

Within the area of community/economic development, nearly half of PRI financing (\$49.6 million) went to urban development projects (Figure 5). The other principal areas of support included rural development, community improvement, and small business development. Compared with the early and mid-1990s, recent PRIs have focused greater emphasis on rural development and business development in U.S. communities and overseas. Two-fifths of PRIs in the development field and 11 percent of PRI dollars financed business startups or capitalized intermediaries that invest in new businesses or provide microcredit.

Although PRI financing remains closely associated with community development and housing, the practice of making, and using, no- or low-interest charitable loans and investments has spread to nearly all fields. In 1998-1999, two-thirds of PRIs and roughly three-fifths of PRI dollars financed projects and organizations in fields other than development, especially education, health, human services, arts and culture, the environment, and religious congregations (Figure 4). Smaller shares of PRI financing supported science and social science, international affairs, and public affairs projects. 
Education. The use of PRI financing for educational institutions has increased dramatically. In 1998-1999, nearly 15 percent of PRI dollars supported education, up from less than 5 percent in 1993-1994. Education's share of PRIs climbed to 16.0 percent, up from 8.3 percent. Of the $\$ 50.4$ million invested in education, approximately one-half ( $\$ 25.8$ million) provided loans for capital projects of higher education institutions or for student loans, while a slightly smaller share financed pre-collegiate education. PRI support for elementary and secondary schools has increased sharply. One of the principal sources of growth in pre-collegiate financing in recent years was the New Jersey-based Prudential Foundation, which is the largest corporate PRI provider. In 1998-1999, Prudential provided 30 loans totaling nearly $\$ 8.3$ million as startup funds for charter schools, almost exclusively in New Jersey.

Health. PRI financing of the health field also grew in the late 1990s. Foundations invested nearly $\$ 47$ million in health projects in 1998-1999. Health's share of PRI dollars increased from less than 6 percent in 1993-1994 to nearly 14 percent in the latest period. PRI activity by the California
FIGURE 5. PRI Financing of Community Development by Subfield, 1998-1999*

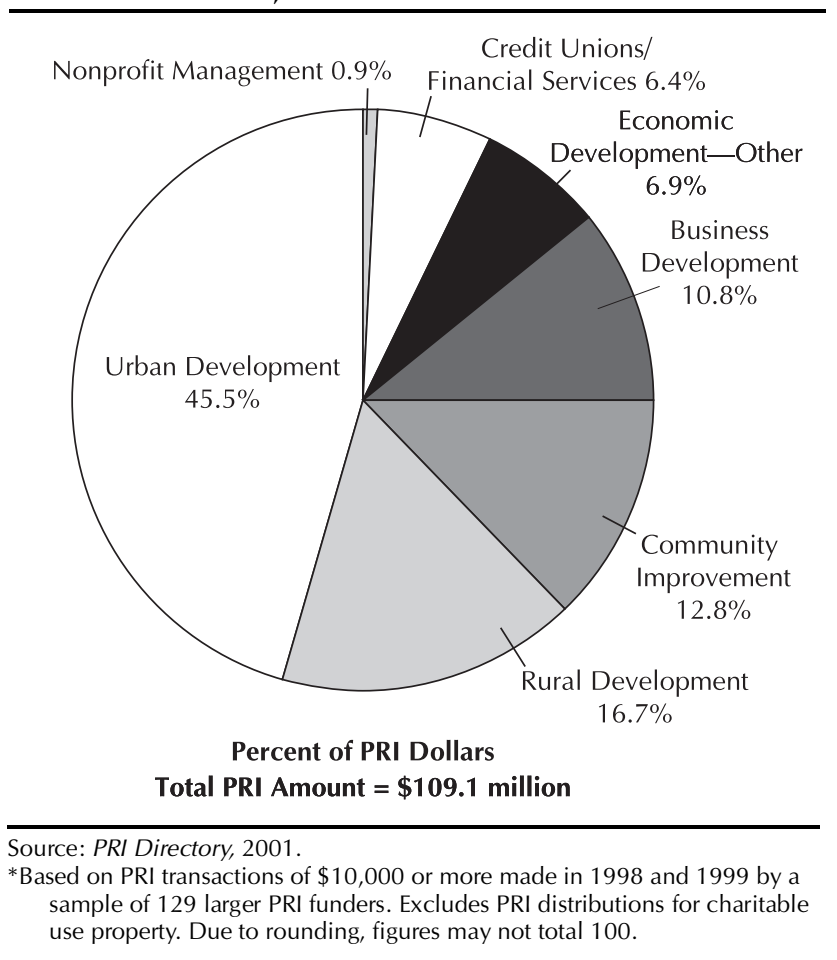

FIGURE 4. PRI Financing by Major Program Areas, 1998-1999*

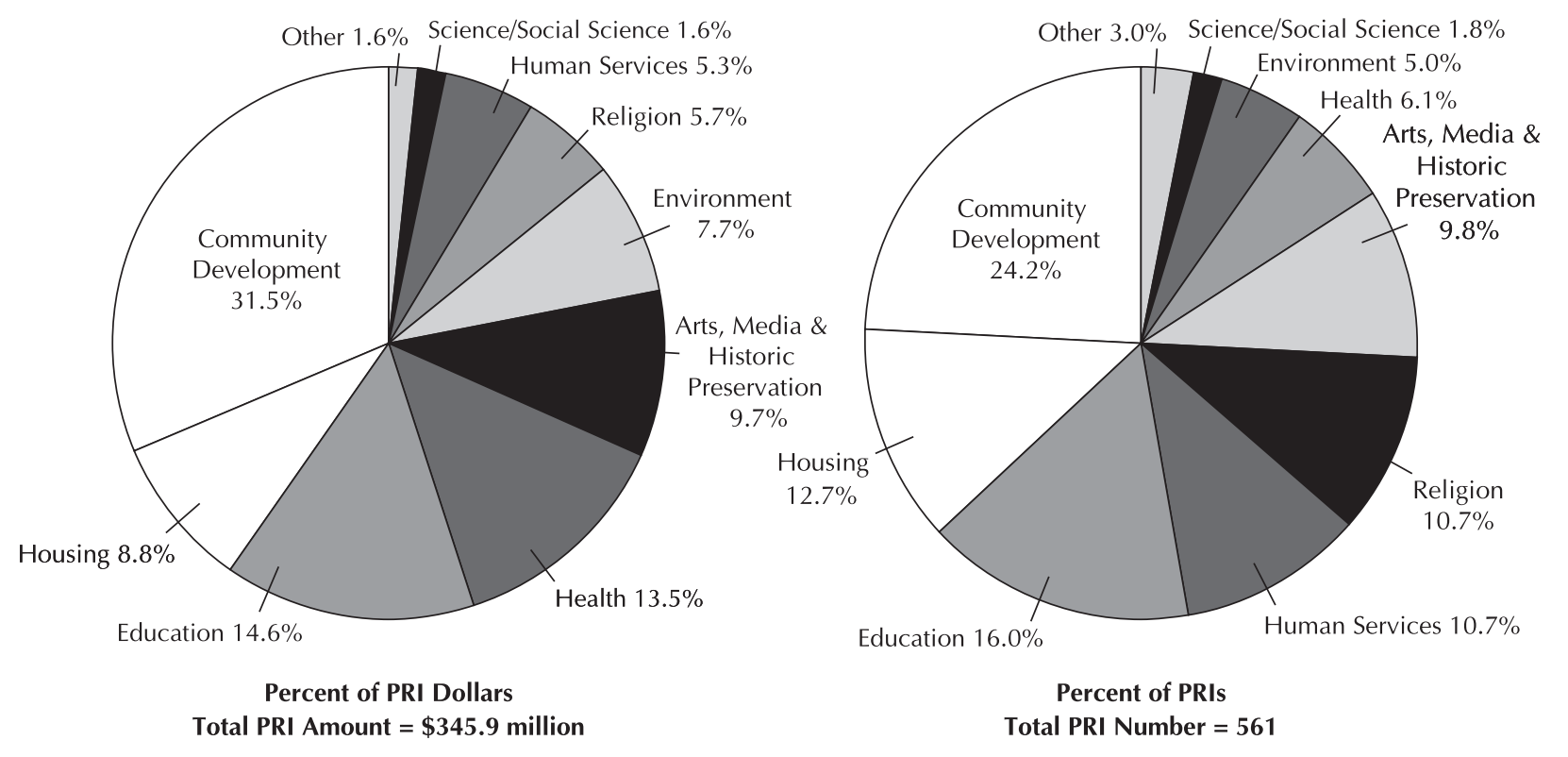

Source: PRI Directory, 2001.

*Based on PRI transactions of $\$ 10,000$ or more made in 1998 and 1999 by a sample of 129 larger PRI funders. Excludes PRI distributions for charitable use property. Due to rounding, figures may not total 100 . 
Endowment, a new health foundation, was in part responsible for the increase in dollar share. The Endowment provided a \$20 million loan in 1999 to the Rural Community Assistance Corporation, a California-based rural development agency, to improve the health of migrant workers. While the share of PRI dollars for health has increased, the share of number of PRIs in the health field has declined. In addition to rural health care projects, which received more than two-fifths of health care support, PRI dollars financed capital projects in general and reproductive health care, medical research, and mental health.

Arts, Media, and Historic Preservation. Foundation loans and investments for arts and culture totaled $\$ 33.6$ million in 1998-1999. One out of ten PRIs and an equal share of PRI dollars supported arts and culture projects. The arts share of PRI dollars has increased since 1993-1994, while its share of PRIs has held steady. PRIs provided capital to independent media organizations overseas (discussed earlier), museums, performing arts groups, historic preservation projects, and humanities projects.

Environment. Environmental projects captured $\$ 26.7$ million in PRI financing, or 7.7 percent. The share for the latest two-year period was consistent with 1993-1994. In the environmental field, PRI financing is mainly used to purchase land for conservation. The Packard Foundation provided a substantial portion of the funds loaned directly to environmental organizations for land conservation projects, especially through the Nature Conservancy. PRIs also supported international conservation and wildlife projects.

Human Services. One out of nine PRIs funded human service projects, down slightly from the mid-1990s. In general, PRIs for human services are among the smallest in size. The amount of financing for human services totaled $\$ 18.4$ million, or a modest 5.3 percent share of PRI dollars. A decrease in the number of community foundations in the sample of PRI providers may explain the drop in share.

Community foundations provide a much larger share of their overall support for human services.

Religion. One out of nine PRIs (10.7 percent) financed capital projects of churches and religious congregations, down slightly from 1993-1994. PRIs for religious groups totaled $\$ 19.6$ million or nearly 6 percent of PRI dollars. Several PRI makers, such as Conrad Hilton, Jessie Ball Dupont, Ervin G. Houchens, and Layne, focus exclusively on supporting religious congregations and churches. Together, they provided a majority of the 60 loans made to religious groups. Most loans for church support were for less than $\$ 100,000$.

\section{Who Receives PRIs?}

PRI recipients can be classified according to their auspices or affiliation. As shown in Figure 6, the vast majority of PRI dollars (80.4 percent) went to nonprofit organizations, either nonsectarian $(70.4$ percent) or religious (10.0 percent). The share of number of PRIs invested with not-for-profits was

FIGURE 6. Distribution of PRI Financing by Recipient Auspices, 1998-1999*

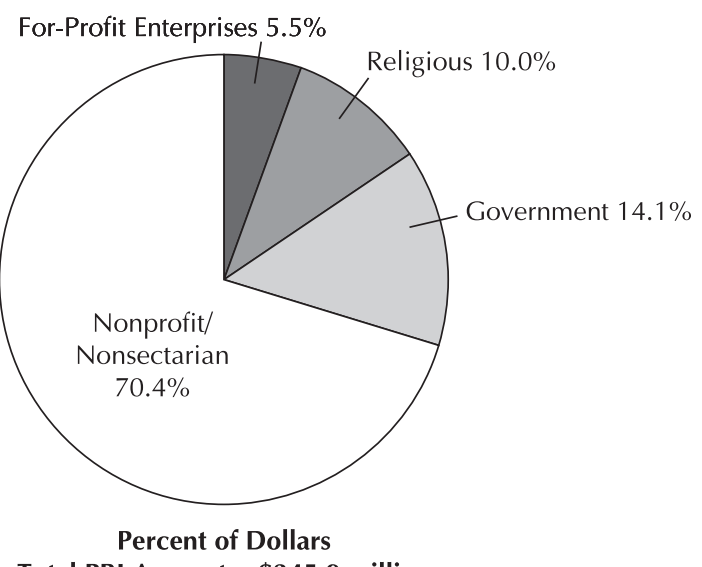

Total PRI Amount $=\$ 345.9$ million

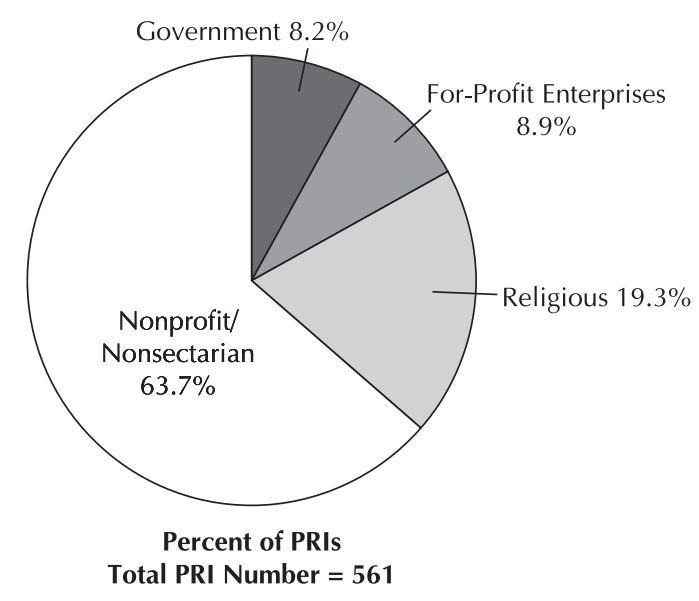

Source: PRI Directory, 2001.

*Based on PRI transactions of \$10,000 or more made in 1998 and 1999 by a sample of 129 larger PRI funders. Excludes PRI distributions for charitable use property. 
TABLE 12. Largest PRI Recipient Organizations, 1998-1999*

\begin{tabular}{|c|c|c|c|c|}
\hline Recipient Name & State & $\begin{array}{l}\text { Dollar } \\
\text { Amount } \\
\text { of PRIs }\end{array}$ & $\%$ & $\begin{array}{l}\text { No. of } \\
\text { PRIs }\end{array}$ \\
\hline $\begin{array}{l}\text { 1. Southeast Wisconsin } \\
\text { Professional Baseball } \\
\text { District }\end{array}$ & WI & $\$ 36,000,000$ & 10.4 & 2 \\
\hline $\begin{array}{l}\text { 2. Rural Community } \\
\text { Assistance Corporation }\end{array}$ & $\mathrm{CA}$ & $20,500,000$ & 5.9 & 2 \\
\hline 3. Nature Conservancy & VA & $12,250,000$ & 3.5 & 3 \\
\hline 4. Danco Laboratories & NY & $9,500,000$ & 2.7 & 1 \\
\hline 5. Bryn Mawr College & $\mathrm{PA}$ & $8,500,000$ & 2.5 & 1 \\
\hline 6. Cornell University & NY & $8,500,000$ & 2.5 & 1 \\
\hline 7. Grove City College & PA & $8,500,000$ & 2.5 & 1 \\
\hline 8. Philadelphia Museum of Art & PA & $8,500,000$ & 2.5 & 1 \\
\hline 9. University of Pennsylvania & PA & $8,500,000$ & 2.5 & 1 \\
\hline $\begin{array}{l}\text { 10. University Heights } \\
\text { Association }\end{array}$ & NY & $7,550,000$ & 2.2 & 2 \\
\hline 11. Neighborhood Progress & $\mathrm{OH}$ & $7,500,000$ & 2.2 & 4 \\
\hline 12. Bridge Housing Corporation & $\mathrm{CA}$ & $7,250,000$ & 2.1 & 2 \\
\hline $\begin{array}{l}\text { 13. Enterprise Corporation of } \\
\text { the Delta }\end{array}$ & MS & $5,250,000$ & 1.5 & 4 \\
\hline 14. Archdiocese of Los Angeles & $\mathrm{CA}$ & $5,000,000$ & 1.4 & 5 \\
\hline 15. Ways to Work & WI & $5,000,000$ & 1.4 & 1 \\
\hline $\begin{array}{l}\text { 16. Southern Development } \\
\text { Bancshares }\end{array}$ & AR & $4,155,030$ & 1.2 & 2 \\
\hline $\begin{array}{l}\text { 17. Kentucky Highlands } \\
\text { Investment Corporation }\end{array}$ & KY & $4,000,000$ & 1.2 & 2 \\
\hline $\begin{array}{l}\text { 18. Survivors of the Shoah } \\
\text { Visual History Foundation }\end{array}$ & $\mathrm{CA}$ & $3,880,000$ & 1.1 & 1 \\
\hline 19. Success for All Foundation & MD & $3,500,000$ & 1.0 & 2 \\
\hline 20. Coastal Enterprises & ME & $3,300,000$ & 1.0 & 3 \\
\hline $\begin{array}{l}\text { 21. East Palo Alto } \\
\text { Redevelopment Agency }\end{array}$ & $\mathrm{CA}$ & $3,300,000$ & 1.0 & 1 \\
\hline 22. Nature Conservancy & $\mathrm{CA}$ & $3,244,000$ & 0.9 & 1 \\
\hline $\begin{array}{l}\text { 23. Resource Area for Teachers } \\
\text { (RAFT) }\end{array}$ & $\mathrm{CA}$ & $3,000,000$ & 0.9 & 1 \\
\hline $\begin{array}{l}\text { 24. New Jersey Performing Arts } \\
\text { Center Corporation }\end{array}$ & NJ & $2,900,000$ & 0.8 & 2 \\
\hline 25. Housing Assistance Council & DC & $2,500,000$ & 0.7 & 2 \\
\hline 26. Illinois Facilities Fund & IL & $2,450,000$ & 0.7 & 6 \\
\hline $\begin{array}{l}\text { 27. Shalem Institute for Spiritual } \\
\text { Formation }\end{array}$ & $\mathrm{DC}$ & $2,320,298$ & 0.7 & 2 \\
\hline $\begin{array}{l}\text { 28. Delaware Valley } \\
\text { Community Reinvestment } \\
\text { Fund (DVCRF) Ventures }\end{array}$ & PA & $2,300,000$ & 0.7 & 3 \\
\hline 29. Angelina College & $\mathrm{TX}$ & $2,100,000$ & 0.6 & 1 \\
\hline $\begin{array}{l}\text { 30. Northern Economic } \\
\text { Initiatives Corporation }\end{array}$ & MI & $2,050,000$ & 0.6 & 2 \\
\hline 31. Palm Beach Atlantic College & $\mathrm{FL}$ & $2,039,633$ & 0.6 & 2 \\
\hline 32. ACCION International & MA & $2,000,000$ & 0.6 & 1 \\
\hline American ORT Federation & NY & $2,000,000$ & 0.6 & 1 \\
\hline $\begin{array}{l}\text { Community Development } \\
\text { Venture Capital Alliance }\end{array}$ & NY & $2,000,000$ & 0.6 & 1 \\
\hline $\begin{array}{l}\text { Community Reinvestment } \\
\text { Fund }\end{array}$ & $\mathrm{MN}$ & $2,000,000$ & 0.6 & 1 \\
\hline Conservation Fund & VA & $2,000,000$ & 0.6 & 1 \\
\hline $\begin{array}{l}\text { Kenya Women Finance } \\
\text { Trust Limited }\end{array}$ & Kenya & $2,000,000$ & 0.6 & 1 \\
\hline Northland Foundation & $\mathrm{MN}$ & $2,000,000$ & 0.6 & 1 \\
\hline
\end{tabular}

slightly higher (83.0 percent), including a 19.3 percent share for religious groups. In contrast, for-profit enterprises received a modest 5.5 percent of financing, or $\$ 19.1$ million in the two-year period. Still, a total of 50 PRIs (or one in eleven) represented loans and investments in small businesses or venture capital funds. (In 1993-1994, only 18 PRIs went to for-profit businesses.) The majority of loans to small businesses were provided by the Maryland-based Development Credit Fund, one of the new PRI providers (est. 1993). The Fund provided 37 loans totaling nearly $\$ 3$ million to small businesses in its home state in 1998-1999.

Table 12 lists the top recipients of PRIs, each receiving at least \$2 million in financing in 1998-1999.

Together these 38 organizations received $\$ 219.3$ million, representing 63.7 percent of all PRI support. The top-ranked recipient with $\$ 36$ million in financing was the Southeast Wisconsin Professional Baseball District, a local government agency created by the Wisconsin state government to oversee construction of a new public baseball stadium complex in Milwaukee. This economic development/sports project received PRI financing in 1998-1999 from the Lynde and Harry Bradley Foundation, which was the top PRI provider in Wisconsin and the third largest in the country.

Most organizations received only one or two PRIs over the two-year period. Exceptions included the Illinois Facilities Fund, a funding intermediary that provides loans to nonprofits for capital projects (six PRIs), the Archdiocese of Los Angeles (five PRIs, including four from the Conrad Hilton Foundation); and four organizations that received four PRIs each: Neighborhood Progress $(\mathrm{OH})$, Enterprise Corporation of the Delta (MS); Strategic Investment Fund (PA); and Women's Capital Corporation (DC). In addition, three organizations received three PRIs each.

Many of the top recipients were financial intermediaries, such as the Kentucky Highlands Investment Corporation and Southern Development Bancshares, or housing and community development agencies, such as the East Palo Alto Redevelopment Agency. However, in contrast with the 1993-1994 sample, top recipients also included several colleges and universities, conservation funds, and arts organizations.

Support for Intermediary Organizations. Of the nearly \$346 million invested directly with recipients, roughly one-fifth ( $\$ 67.5$ million) provided capital to "intermediary" organizations, which in turn lent funds to development and housing agencies, job training agencies, community organizations, arts groups, and other borrowers. (In the Foundation Center's PRI 
database, intermediaries include loan funds, credit unions, development banks, microenterprise funds, and venture capital funds.) Intermediaries received a 22 percent share of the number of PRIs.

The proportion of PRI financing provided through intermediaries has declined. In 1993-1994, roughly half of all PRI dollars supported intermediaries, and four of the five top recipients were intermediaries (the two largest were the Local Initiatives Support Corporation and the National Community Redevelopment Initiative). The trend toward stronger support for individual users reflects substantial changes among the top PRI providers. Throughout the early and mid-1990s, the very largest PRI providers - Ford and MacArthur-invested a large majority of their PRI portfolios with intermediaries. Since Ford and MacArthur represented nearly two-fifths of all PRI financing, the practices of these two funders dominated recipient patterns. In contrast, in the most recent two-year period, two of the three top providers (Pew and Bradley) provided all of their PRIs directly to recipients for their own projects, while the Packard Foundation funded both individual organizations and intermediaries.

\section{The Purposes of PRI Financing}

All PRIs provide needed capital to their recipients. Nevertheless, like grants, these charitable loans and investments are used for various purposes. Figure 7 shows the major purposes of the 561 PRIs in the 1998-1999 sample. Roughly half of PRI dollars financed capital projects. Building, renovation, and equipment represented nearly 36 percent of dollars, while other projects (e.g., building or land purchases) represented an additional 15 percent.

Since the mid-1990s, the use of PRIs for other purposes has increased. For example, the share of PRI dollars for special (non-capital) projects and programs jumped to one-third, up from only 16 percent. Lesser shares of PRI support funded student loans (5 percent), research (4 percent), and operating support (2 percent). Some PRIs provided more than one type of support. ${ }^{10}$

10. For lack of information, more than 30 percent of PRI dollars and nearly 45 percent of PRIs could not be identified according to purpose or use of funds.

\section{PRI Financing by Major Beneficiary Group}

The Center's classification system includes major beneficiary groups organized by age, gender, race or ethnicity, socioeconomic group, and other categories shared with the National Center for Charitable Statistics. PRIs received a population group code whenever the intended beneficiary was noted in the PRI description or when the beneficiary was clear from the name and purpose of the recipient organization.

Of the nearly $\$ 346$ million lent or invested with recipients, more than two-fifths of the dollars (42

FIGURE 7. PRI Financing by Major Type of Support, 1998-1999*

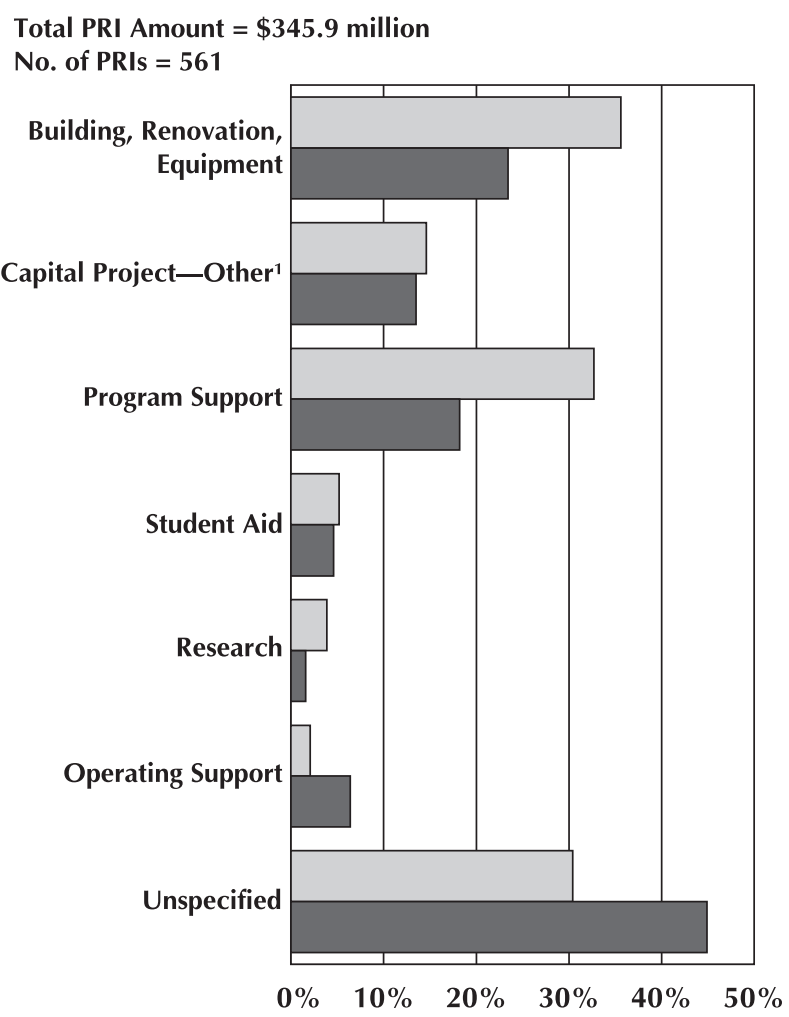

Percent of PRI Dollars

Percent of PRIs

Source: PRI Directory, 2001.

* Based on PRI transactions of $\$ 10,000$ or more made in 1998 and 1999 by sample of 129 larger PRI funders. Excludes PRI distributions for charitable use property. PRIs may occasionally be earmarked for multiple purposes and would therefore be counted more than once.

${ }^{1}$ Includes capital campaigns, building purchase, land acquisition, debt reduction, and other capital projects. 
percent) and nearly two-fifths of the PRIs (39 percent) targeted a specific population group. Figure 8 shows the percentage of dollars and number of PRIs benefiting the four best-funded beneficiary groups, each receiving at least 4 percent of funds. Nearly 29 percent of PRI dollars and nearly an equal share of PRIs financed projects serving the economically disadvantaged, including the urban and rural poor, the homeless, and migrant workers. More than 11 percent of PRI dollars and 9 percent of PRIs provided capital for projects serving ethnic or racial groups, including African Americans or black populations overseas, Native Americans/American Indians, Asians and Pacific Islanders, and Hispanics/Latinos. Nearly 8 percent of PRI funds supported projects benefiting women and girls, especially economic and health projects, while almost 5 percent financed projects benefiting children and youth. Much smaller percentages of PRI dollars funded projects serving other groups, such as the disabled ( 2 percent) and the aging (1 percent).

With its emphasis on neighborhood revitalization, low-income housing, microbusiness promotion, and job creation, charitable lending and investing is targeted to a far greater extent than grantmaking toward the economically disadvantaged. For example, in 1999, only 12 percent of grant dollars were earmarked specifically for the poor and low-income groups, compared with 29 percent of PRI distributions. Similarly, only 14 percent of the number of grants were aimed directly at low-income groups, compared with 27 percent of PRIs.
FIGURE 8. PRI Financing by Major Beneficiary Group, 1998-1999*

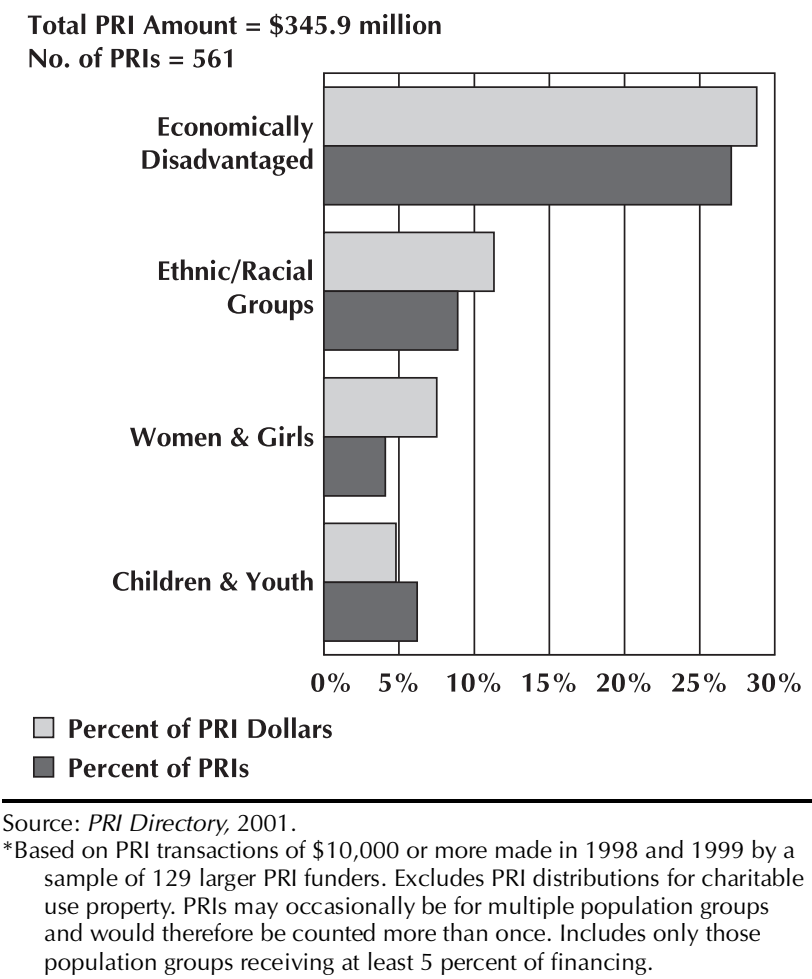

\section{Ordering Information}

The PRI Directory: Charitable Loans and Other Program-Related Investments by Foundations, 2001 Edition, may be charged with Visa, MasterCard, or Amex by calling our toll-free number, 800-424-9836 (in New York, call 212-807-3690); by using our on-line order form at http://www.fdncenter.org; or by mailing orders to the Foundation Center, Dept. PR, 79 Fifth Avenue, New York, NY 10003-3076. Prepayment of $\$ 75.00$ is required. Discounts are available for bulk orders. Please call 800-424-9836 for details. 


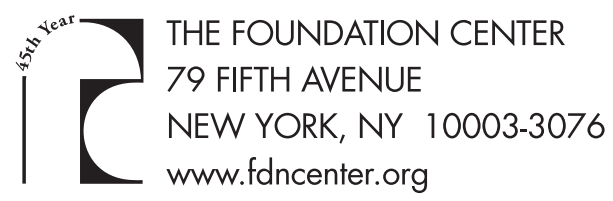

